Kuronen, M., P. Lintunen \& T. Nieminen (toim.) 2017. Näkökulmia toisen kielen puheeseen Insights into second language speech. AFinLA-e. Soveltavan kielitieteen tutkimuksia 2017 / n:o 10. $163-192$.

\author{
Mari Honko \\ Jyväskylän yliopisto
}

\title{
Sadutettu sanasto: puhutun kielen leksikaalinen diversiteetti arviointikohteena
}

This study analyses lexical diversity (sums of probabilities) in spoken narratives of L1 and L2 school age children $(n=99)$ and compares the results to the lexical diversity of written narratives of the group of comparison. The key research questions are: a) does the lexical diversity of the spoken narratives systematically differ from the lexical diversity of written narratives and b) does the lexical diversity of spoken narratives systematically differ depending on five individual variables: lexical skills, language proficiency, L1, gender and age of the speaker? All the narratives are produced in Finnish in storytelling events during the spring semester of the $2 \mathrm{~d}$ and 3 rd school year. Sums of probabilities is an index of lexical diversity. It is based on widely used D (Malvern \& Richards 1997) and can be used with texts that differ in length and genre.

The results reveal a weak but significant difference between the lexical diversity of spoken and written narratives and weak but complex correlations between the lexical diversity of spoken narratives and the proficiency level as well as the lexical skills of the child. However, there is no correlation or other appreciable connection between the lexical diversity and language background ( $\mathrm{L} 1 / \mathrm{L} 2)$, gender or the school grade of the child. In addition, in $\mathrm{L} 2$ group there is no connection between the lexical diversity and the length of residence in Finnish speaking environment or, between the lexical diversity and the specific language difficulties observed by their teacher, either. The results are discussed and compared with the individual differences in turns and turn-taking during the storytelling event tentatively.

Keywords: lexical diversity, vocabulary skills, language learning, school age

Asiasanat: leksikaalinen diversiteetti, kielen oppiminen, toinen kieli, kouluikäiset 


\section{Johdanto}

Artikkelissa tarkastellaan puhutun kielen leksikaalista diversiteettiä (lexical diversity), josta on suomenkielisessä kirjallisuudessa käytetty myös nimityksiä sanaston monimuotoisuus ja rikkaus (Malin 2012), monipuolisuus (Honko 2013) ja vaihtelevuus (Taimisto 2014). Leksikaalisen diversiteetin on havaittu olevan yhteydessä mm. kielenkäyttäjän mentaalileksikon kehittyneisyyteen sekä kokonaiskielitaitoon ja vaikuttavan niin kielen ilmaisuvoimaan kuin kielenkäyttäjästä muodostettuihin tulkintoihinkin (ks. esim. Bradac \& Wisegarver 1984; Burroughs 1991; Malvern ym. 2004; Jarvis 2013a,b). Leksikaalista diversiteettiä on lukuisten tutkimusten perusteella pidetty lupaavana leksikaalisen tiedon ja taidon indikaattorina, sillä sen on katsottu peilaavan paitsi yksilön sanavaraston laajuutta ja kompleksisuutta myös hänen kykyään käyttää leksikaalisia resursseja tehokkaasti (ks. esim. Malvern \& Richards 2002: 85; Malvern ym. 2004; Jarvis 2013a,b). Lisäksi leksikaalisen diversiteetin mittaamista ja tutkimista on pidetty hyödyllisenä tapana kuvata erilaisten tekstien laatua laajemminkin (McCarthy \& Jarvis 2007: 476, 482-483; Yu 2010).

Tämän artikkelin tehtävänä on selvittää, a) poikkeaako kouluikäisiltä lapsilta kerättyjen puhuttujen kertomusten leksikaalinen diversiteetti aiemmin (Honko 2013) tutkittujen kirjoitettujen kertomusten diversiteetistä (luku 4.1) ja b) onko puhuttujen kertomusten leksikaalisessa diversiteetissä systemaattisia ryhmäkohtaisia eroja, jotka selittyvät lapsen kielitaidolla, ensikielellä, sukupuolella tai iällä (tarkemmin luku 4.2). Lisäksi tarkastellaan sitä, vaikuttaako aikuisen sadutustilanteessa tuottama sanasto lapsen kertomuksen leksikaaliseen diversiteettiin (luku 4.3). Tulosten kontekstoimiseksi kussakin analyysiosion alaluvussa esitellään myös aiemman tutkimuksen, erityisesti kirjoitelmaaineistoon pohjautuvan verrokkitutkimuksen (Honko 2013), tuloksia. Havaintojen pohjalta arvioidaan, voisiko leksikaalinen diversiteetti toimia kehityksellisenä mittarina vastaavia aineistoja analysoitaessa. Vaikka leksikaalista diversiteettiä on aiemmassa tutkimuksessa hyödynnetty jo melko laajalti, sen määritelmä ja mittaustapa eivät ole vakiintuneet, minkä vuoksi tämän tutkimuksen rajaukset perusteluineen esitellään yksityiskohtaisesti luvussa 3.

Tämän tutkimusartikkelin varsinaisena aineistona on sadan alakouluikäisen lapsen suomenkielinen sadutusaineisto, joka on kerätty yhtenevän puolistrukturoidun tehtävänannon avulla. Tutkitun ryhmän lapset ovat iältään 811-vuotiaita ja edustavat eri kieli- ja kulttuuriryhmiä. Mukana on sekä suomea ensimmäisenä että toisena kielenä omaksuvia lapsia. Kieliaineistojen ohella käytettävissä on kyselytietoa muun muassa tutkimukseen osallistuneen lapsen kielitaidosta sekä iästä, Suomessa asumisen kestosta ja varhaislapsuudessa käytetyistä kielistä. Lisäksi käytettävissä ovat tulokset sanastonhallintaa erikseen mittaavasta strukturoidusta testistä. Sadutusmenetelmä, aineiston eri osiot ja analyysimetodit esitellään tarkemmin luvussa 3. Kirjoitetun kie- 
len aineisto mahdollistaa leksikaalisen diversiteetin vertailun modaliteettien eli puheen ja kirjoituksen välillä ja toisaalta pakottaa metodin kriittiseen arviointiin: esimerkiksi se, että puhekieli harvoin jakautuu siististi ehyiksi ja erillisiksi leksikaalisiksi yksiköiksi, asettaa aineiston analysoinnille kirjoitetun kielen teksteistä poikkeavia haasteita.

Alakouluiässä sanaston määrällinen ja laadullinen kehitys on kiivasta ja yksilölliset erot sanaston hallinnassa suuria (ks. Honko 2013). Erot lasten leksikaalisissa valmiuksissa ovat merkityksellisiä, sillä vahva sanastonhallinta on laaja-alaisesti yhteydessä kielelliseen suoriutumiseen kuten luku- ja kirjoitustaitoon ja siten esimerkiksi kykyyn ottaa haltuun koulun oppisisältöjä (Saarela 1997; Alderson 2005; Tannenbaum ym. 2006; Milton 2009; Lervåg \& Aukrust 2010). Sanastollinen osaaminen myös ennustaa menestymistä kielellisissä taidoissa myöhemmin: vahva sanasto helpottaa sekä kielellä toimimista että sen edelleen kehittämistä (Cain ym. 2004; Dockrell \& Messer 2004; Muter ym. 2004; Qian \& Schedl 2004; Honko 2013). Lapsuusiän kielitaitotutkimuksen avulla voidaan tunnistaa sanastollisten valmiuksien puutteita ja pyrkiä ennaltaehkäisemään erojen kasvua paitsi suoran kielellisen tuen avulla myös esimerkiksi tukemalla lasten sosiaalisia suhteita ja monipuolisia kielenkäyttömahdollisuuksia (Verhoeven 1990: 106-107). Siksi leksikaalisten taitojen tutkiminen on perusteltua juuri koulunaloitusvaiheessa. Leksikaalisen diversiteetin kiinnostavuus arviointi- ja diagnosointivälineenä perustuu ennen kaikkea sen potentiaaliin hyvin monenlaisten tekstien arvioimisessa sekä selkeisiin, laskennallisia menetelmiä hyödyntäviin analyysimalleihin ja niiden toistettavuuteen.

Eroja leksikaalisessa diversiteetissä on aiemmissa tutkimuksissa havaittu muun muassa lasten ja aikuisten sekä eri-ikäisten lasten ja nuorten kirjoittamissa teksteissä (Berman \& Verhoeven 2002; Johansson 2008) sekä jo varhaislapsuudessa eri-ikäisten lasten puheessa niin tyypillisen (Durán ym. 2004) kuin epätyypillisen kielenkehityksen yhteydessä (Klee ym. 2004). Leksikaalista diversiteettiä on pidetty potentiaalisena kehityksellisenä mittarina, mutta näyttö on toistaiseksi vahvinta kielenkehityksen alkuvaiheessa eli ensikielen osalta varhaislapsuudessa ja toisen kielen osalta alimmilla taitotasoilla.

Aiempi tutkimus on tehty suureksi osaksi englanti toisena ja vieraana kielenä -kontekstissa (ks. kuitenkin esim. Castañeda-Jiménez \& Jarvis 2014). Koska leksikaalinen diversiteetti on kytköksissä tarkasteltavan kielen morfologiseen ja syntaktiseen rakenteeseen, eri kieliä koskevat tutkimustulokset eivät ole suoraan vertailukelpoisia (Dewaele $\&$ Pavlenko 2003: 132-133; Strömqvist ym. 2002). Uutta tietoa tarvitaankin sekä puhutun kielen leksikaalisesta diversiteetistä yleisesti että leksikaalisen diversiteetin soveltamisesta erityisesti suomenkieliseen puhutun kielen aineistoon.

Tämä tutkimus rajataan tyypillisesti kehittyvien lasten puhutun kielen leksikaalisen diversiteetin tarkasteluun, sillä aiempien tutkimusten tulokset etenkin puhutun kielen aineistosta ovat ristiriitaisia (ks. Watkins ym. 1995; Scott \& 
Windsor 2000; Vermeer 2000; Wong ym. 2010; Ellis ym. 2015; Lai \& Schwanenflugel 2016). Tuloksia verrataan lasten muuhun kielelliseen osaamiseen sekä aiemmassa kirjoitettuun kieleen kohdistuneessa tutkimuksessa saatuihin tuloksiin. Lisäksi tuloksia arvioidaan suhteessa niihin yksilöllisiin taustatekijöihin, joiden on aiemmassa tutkimuksessa havaittu vaikuttavan leksikaaliseen diversiteettiin.

\section{Leksikaalinen diversiteetti kielitaidon arvioinnissa}

Leksikaalisen diversiteetin hyödyntäminen kielitieteellisessä tutkimuksessa juontaa juurensa 1930-luvun loppupuolelle John Carrollin artikkeliin "Diversity of vocabulary and the harmonic series law of word frequency distribution", jossa Carroll (1938: 379) määritteli diversiteetin (diversity) sanaston suhteelliseksi toisteisuudeksi tai vaihteluksi tietyssä tekstissä ("the relative amount of repetitiveness or the relative variety in vocabulary"). Myöhempiin määritelmiin on vaihtelevasti sisällytetty myös sanojen sironta eli sijoittuminen tekstiin ja sanavalikoiman laatu, kuten käytettyjen sanojen harvinaisuus kielessä ja yksilöllisyys tarkastellussa useamman tekstin aineistossa (Malvern ym. 2004; Jarvis 2013b). Vaikka leksikaalista diversiteettiä on varhaislapsuuden jälkeen sovellettu enimmäkseen kirjoitetun kielen tutkimukseen, se koskee jo Carrollin mukaan sekä puhuttua että kirjoitettua kieltä ja on riippuvainen monista tekijöistä kuten tekstin tuottajan iästä, älykkyydestä ja taustasta. ${ }^{1}$ Leksikaalisen diversiteetin määrittelytapa, sen tutkimisessa käytetty käsitteistö tai analyysimetodit eivät kuitenkaan ole vakiintuneet, mikä vaikeuttaa sekä tutkimustulosten vertailua että itse tutkimusmetodin arviointia.

Ajatus tietyn tekstin tai tekstikokoelman leksikaalisen diversiteetin yhteydestä tekstintuottajan ominaisuuksiin ja taustaan on tehnyt siitä monien tutkijoiden mielestä kiinnostavan metodin juuri kielitaidon arvioinnin näkökulmasta. Tyypillisesti on verrattu kielenoppijoiden ja äidinkielisten kielenpuhujien tekstejä, tarkasteltu eri-ikäisten ja eri kielitaitotasoa edustavien kielenoppijoiden tekstejä tai analysoitu eriasteisista kielihäiriöistä kärsivien tekstejä suhteessa tyypillisen kielenkehityksen ryhmään. Havaintojen mukaan korkea kielitaitotaso (sekä L1 että L2) ja tyypillinen kielenkehitys (vs. kielihäiriö) ovat tietyin varauksin yhteydessä runsaampaan leksikaaliseen diversiteettiin, ja puheen leksikaalisella diversiteetillä on arvioitu olevan vaikutusta myös siihen,

Carroll itse (1938) pohjasi työnsä Zipfin $(1935,1937)$ aiempiin julkaisuihin, joissa diversiteetti määriteltiin kapeammin yksittäisten sanojen toiston ja esiintymisvälien kautta ("average rate of repetitiveness"). Toisaalta jo Zipf nosti esille muun muassa sanatoisteisuuden vaikutuksen tekstin vastaanottajan (lukijan tai kuulijan) kokemukseen, mikä ei myöhemmässä tutkimuksessa ole saanut juuri huomiota ennen kuin aivan viime vuosina (ks. myös Jarvis 2013b; Castañeda-Jiménez \& Jarvis 2014). 
millaisia tulkintoja kuulija tekee puhujasta ja kuinka tähän suhtautuu. ${ }^{2}$ Miltonin (2009: 127) esittämän tiivistyksen mukaan kielellisen sujuvuuden lisääntyessä ja taitotason noustessa tuotetun kielen sanaston variaatiokin vähitellen kasvaa. Tuoreimmissa tutkimuksissa leksikaalista diversiteettiä on pidetty lupaavana mittarina myös kielellisen attrition osoittamisessa: attrition myötä leksikaalinen diversiteetti vähenee (Schmid \& Jarvis 2014).

Leksikaalisen diversiteetin soveltaminen oppijankielentutkimukseen perustuu kahteen keskeiseen oletukseen: a) kielenoppimisen myötä osattujen sanojen määrä ja sanojen käyttämisessä tarvittava tieto karttuu ja b) karttuva osaaminen heijastuu suoraan henkilön tuottamien tekstien sanastoon: käytetystä mittarista riippuen joko pelkästään määrään ja vaihteluun tai määrään, vaihteluun ja laatuun. Tekstin leksikaalista diversiteettiä voidaan kasvattaa vain, jos siihen lisätään uutta sanastoa, ja siksi runsas diversiteetti jo kohtuullisen pitkissä teksteissä väistämättä edellyttää myös kielen harvinaisen sanaston käyttöä - ja siten laajaa aktiivista sanavarastoa.

\section{Aineisto ja metodit}

\subsection{Sadutusaineiston yleisesittely}

Perusaineisto koostuu 103 puhutusta kertomuksesta, jotka on kerätty saduttamalla, litteroitu ja syötetty Excel-tietokannaksi (ks. tarkemmin luku 3.2). Sadutus on osallistava metodi, jossa sadutettavaa pyydetään kertomaan suullisesti satu tai tarina vapaasti haluamastaan aineesta tai joskus myös rajatummin tietystä aiheesta. Tässä tutkimuksessa käytössä on aihesadutus, ja aihe (kerro satu tai tarina Unelmien päivästä) sekä ohjeistus ovat samat kuin kirjoitettujen kertomusten leksikaalista diversiteettiä käsittelevässä verrokkitutkimuksessa (Honko 2013). Sadutusmetodia on tyypillisesti käytetty arjen työkaluna lasten parissa, mutta sitä on hyödynnetty myös tutkimuksessa ja aikuisten kanssa. (Ks. Karlsson 2013, 2014; Riihelä 2013; metodin varhaisvaiheista esim. Riihelä 1991.) Tukea juuri sadutusmetodin käyttämiseen diversiteettitutkimuksessa löytyy epäsuorasti myös aiemmasta lingvistisestä tutkimuksesta, sillä Schmid ja Jarvis (2014) pitävät vapaasti tuotetun puheen leksikaalisen diversiteetin tarkastelua validimpana vaihtoehtona kuin muodollisten tehtävien tai kontrolloitujen kertomusten (elicited narratives) avulla kerätyn aineiston tarkastelua. Kaikkien sadutustuokioiden olosuhteet, tehtävänanto ja kerronnan aihe sekä aineiston käsittelytapa ovat olleet yhtenevät, mikä on kertomusten leksikaalisen diversiteetin vertailtavuuden kannalta tärkeää (Durán ym. 2004: 75).

Ks. Bradac \& Wisegarver 1984; Burroughs 1991; Watkins ym. 1995; Scott \& Windsor 2000; Jarvis 2002; Dewaele \& Pavlenko 2003; Wright ym. 2003; Durán ym. 2004: 234; Malvern ym. 2004; Unsworth 2004: 317-318, 322; Tidball \& Treffers-Daller 2007; Yu 2010; Jarvis 2013a,b; Honko 2013; Gregori-Signes \& Clavel-Arroitia 2015. 
TAULUKKO 1. Sadutettujen kertomusten määrä. Taulukossa on esitetty kertomusten kokonaismäärät ryhmittäin. Sulkeissa on lisäksi esitetty asetetun pituusehdon täyttävien ja siten analyyseihin nostettujen kertomusten kokonaismäärä.

\begin{tabular}{lccccc}
\hline & S1 & S2 & S1 & S2 & yht. \\
\hline pojat & $5(4)$ & $20(19)$ & 8 & 16 & $49(47)$ \\
tytöt & 4 & $25(23)$ & 15 & 10 & $54(52)$ \\
yht. & 9 & 45 & 23 & 26 & $103(99)$ \\
\hline
\end{tabular}

TAULUKKO 2. Sadutettujen kertomusten kokonaissanamäärät.

\begin{tabular}{lrrrrr}
\hline & min & maks. & ka & kh & md \\
\hline saneita & 57 & 1380 & 305 & 245 & 227 \\
eri sanoja & 14 & 312 & 107 & 57,6 & 93 \\
\hline
\end{tabular}

Sadutustuokion keskimääräinen kesto on noin 20 minuuttia.

Lyhyimmät, alle 50 saneen kertomukset $(n=4)$ on poistettu aineistosta ennen analyyseja. 50 saneen rajaa on pidetty tulosten luotettavuuden kannalta turvallisena vaihtoehtona, ja se vastaa kirjoitettujen kertomusten analysoinnissa tehtyä rajausta (ks. Durán ym. 2004: 228; Honko 2013: 363). Taulukossa 1 on eritelty tois- ja kolmasluokkalaisten, tyttöjen ja poikien sekä ensikielisten (S1) ja suomi toisena kielenä -oppijoiden (S2) aineisto. Kokonaismäärä (99) on tilastollisten analyysien kannalta riittävä. Alaryhmät (erityisesti ensikieliset suomenpuhujat, $n=32$ ) ovat kuitenkin pienet ja jokaiselta puhujalta on tutkittu vain yhden sadutuskerran aineisto, minkä vuoksi tulosten yleistämisessä täytyy noudattaa varovaisuutta. S2-ryhmän lapsissa ei ole maassaoloajan ( $\geq 2$ vuotta) ja koulunkäynnin vaiheen (yleisopetuksen 2.-3. Ik.) perusteella aivan alkeistason suomenoppijoita.

Vaikka tehtävänanto ja saduttaja olivat kaikissa sadutustuokioissa samat, tuokioiden kulussa oli paljon vaihtelua: osa lapsista eteni kerronnassa yksittäisin sanoin ja lausekkein, osa kertoi vuolaasti ja pitkään. Sadutustuokion vuorojäsennystä havainnollistavat liitteiden 1 ja 4 esimerkkilitteraatit ja kertomusten pituuseroja taulukko 2, johon on koottu kertomusten sanemäärän osoittavat tunnusluvut (keskipituus, suurin ja pienin pituus, keskihajonta, mediaani). Lapsen puhe on lähtökohtaisesti sisällytetty kertomukseen kokonaisuudessaan (ks. aineiston käsittely ja poistot tarkemmin luku 3.2). Pisin tietokantaistettu kertomus on 1380 ja lyhin 57 sanetta, keskipituus 305 ja keskihajonta 245 sanetta, eli hajonta on suuri. Aineiston kokonaissanemäärä on 30 641 ja eri sanojen määrä 2 229. Sadutusaineiston kertomukset ovat huomattavasti pitempiä kuin samanikäisten lasten samalla tehtävänannolla kirjoittamat 
tekstit (2. vuosiluokan keskipituus 53 ja kolmannen 83 sanetta, kun kirjoitusaika oli n. 45 minuutin, ei tarkkaa aikarajausta).

\subsection{Aineiston käsittely: kontekstina puhuttu kieli}

Puhe ei lukupuhuntaa lukuun ottamatta yleensä jakaudu siististi peräkkäin lausuttujen kokonaisten sanojen muodostamiksi lauseiksi, vaan keskustelu etenee toisiinsa lomittuvina vuoroina, joihin voi sisältyä kesken jääneitä ilmauksia, epäröintejä, toistoja ja korjauksia. Sanojen rajat voivat kadota tai olla häilyviä, jolloin syntyy kahden tai useamman sanan yhteensulautumia. Käytetyissä ilmauksissa ja niiden muodossa voi olla vaihtelua sekä eri yksilöiden välillä että samankin yksilön puheen eri kohdissa ja eri puhetilanteissa. Lisäksi sisältöjä ja merkityksiä voidaan rakentaa yhdessä tai kierrättää toisten puheesta.

Sadutus toisaalta poikkeaa arkisesta vuorovaikutustilanteesta epäsymmetrisyydellään: sadutuksessa on yleensä läsnä tilannetta ohjaava aikuinen sekä lapsi. Vuorovaikutuksessa ei pyritä tasaiseen vuorotteluun, vaan aikuisen perustehtävä on alkuorientaation ja -ohjeistuksen jälkeen tukea lapsen kertomista mutta antaa ensisijainen puhetila lapselle ja välttää kertomisen ohjailua. (Karlsson 2014.) Saduttaja välttää tuomasta kerrontaan omia aineksiaan kuten juonirakenteita tai valmiita ilmauksia, mikä vähentää sekä vuorojen kerrostuneisuutta (kierrättämistä, yhdessä rakennettuja lausekkeita) että päällekkäispuhuntaa ja kesken jääneitä ilmauksia (liite 1; luku 4.3; myös Honko 2017).

Eri tekstien diversiteettiarvojen vertailu edellyttää saman mittarin käyttämistä sekä tietokannaksi syötettäessä aineiston samanlaista käsittelytapaa eli tekstin kirjoitusasun yhdenmukaistamista ja mittarissa käytettävän leksikaalisen yksikön määrittelemistä (Durán ym. 2004: 228). Tässä tutkimuksessa litteroidut ja toisen kuuntelijan tarkistamat sadutustuokiot on syötetty Exceltietokannaksi seuraavien periaatteiden mukaan:

1. Lapsen tuottama puhe on tuotu Excel-tietokantaan (kukin sane omalle rivilleen) ja lemmattu kokonaisuudessaan sadutuksen orientaatio- ja lopetusvaihetta lukuun ottamatta.

2. Tietokannan perusyksikkö leksikaalisen diversiteetin tarkastelussa on perusmuotoinen sana (lemma), jota kirjoituksessa yleensä vastaa yksi sanavälein erotettu yksikkö (pelata, nopeasti, hipi hiljaa).

3. Taivutusmuodot ja foneettiset sekä murteelliset varieteetit (pelata, belaa, pelattii; simmottii, semmosii) kuuluvat samaan sanaan yleiskielisen varieteetin kanssa ja on lemmattu samalla tavalla (pelata, semmoinen). Menettelytapa mahdollistaa tulosten vertaamisen lasten kirjoitetun kielen korpuksesta havaittuun. ${ }^{3}$

3 On kuitenkin syytä huomata, että esimerkiksi perosoonapronominien tapauksessa puhe- 
4. Epäröintiäännähdyksiä tai sanan toistettuja osia ei ole lemmattu (ssitten > sitten niin et ää- > niin, että; tul- mentiin > mennä, hää- juhlavaatteet > juhlavaate). Toisinaan lapsen vuorosta voi päätellä, että epäröinnillä on myös sisällön rajoittamisen funktio (Ara- Irakii; sitten se Antse poika otti).

5. Kokonaisten sanojen toistamisella on kertomuksissa usein selkeä sisällöllinen funktio (Kuusi oli hyvin hyvin iloinen). Siksi toistetut sanat on lemmattu erikseen, kuten kirjoitetun kielen aineistossakin.

6. Monisanaiset erisnimet ja kiteytyneet ilmaukset on lemmattu yhtenä sanana.

7. Sanojen yhteen sulautumat ( $f=436$, ks. myös ISK 2004: $§ 140$ ) kasautuvat aineistossa samoille puhujille, ja ne on eroteltu yleiskielen mukaan kuten verrokkikorpuksessakin (son > se, olla, mostettiin > me, ostaa; sillee / sillai / sillei > sillä lailla, miksei > miksei).

8. Epäröinti-ilmauksia kuten öö-, ä- ja dialogipartikkelia $m m$ ei ole lemmattu.

9. Sanat on raakalemmattu aakkostetusta sanalistasta. Kaikki monitulkintaiset muodot (esim. et > että tai ei; leikkii > leikki tai leikkiä; ankkuja $>$ ankka, punkkoja > punkka) on merkitty lemmauksen yhteydessä värikoodilla ja lemmattu lopullisesti juoksevasta tekstistä esiintymisympäristön perusteella.

10. Kokonaan tunnistamattomat sanat (esim. hyvin hiljaisesti äännetyt tai häiriöäänen peittämät) on jätetty analyysin ulkopuolelle. Tällaisia sanahahmoja koko aineistossa on kuitenkin vain noin 20 ja osuus aineistosta marginaalinen.

\subsection{Kirjoitetun kielen verrokkiaineisto ja kyselyaineistot}

Artikkelin ensimmäisessä analyysiosiossa (luku 4.1) puhutun kielen aineiston leksikaalista diversiteettiä peilataan kirjoitetun kielen leksikaaliseen diversiteettiin. Kirjoitelma-aineisto on kerätty, lemmattu ja analysoitu jo aiemmin tämän tutkimuksen kanssa yhteneviä periaatteita noudattaen. Aineiston määrä on koottu taulukkoon 3 kirjoittajaryhmittäin.

Yksilöllisinä vertailumuuttujina aineiston tarkastelussa käytetään lapsen kielitaitoa, ensikieltä, sukupuolta tai ikää. Kielitaidon yleistasoa on mitattu summamuuttujalla, joka koostuu kyselytietona kerätyistä kielitaitoarvioista

kieliset muodot ovat korpuksessa yleiskielisiä muotoja yleisempiä (esim. $m a ̈ f=960$, minä $f=604 ; \operatorname{sä~} f=40$, sinä $f=15)$. 
TAULUKKO 3. Kirjoitelma-aineiston kertomusten määrä. Taulukossa on esitetty pituusehdon täyttävien kertomusten kokonaismäärät ryhmittäin.

\begin{tabular}{lllrrr}
\hline & S1 & S2 & S1 & S2 & yht. \\
\hline pojat & 20 & 10 & 37 & 19 & 86 \\
tytöt & 47 & 13 & 69 & 25 & 154 \\
yht. & 67 & 23 & 106 & 44 & 240 \\
\hline
\end{tabular}

kolmella kielitaidon osa-alueella: puhuminen, kirjoittaminen ja sanasto. Summamuuttujat on koostettu sekä lapsen itsearvioinneista että lapsen opettajalta pyydetyistä kielitaitoarvioista. Opettajan arviot ovat 5-portaisia (mahdolliset arvot 1-5, vaihteluväli summamuuttujan arvoissa 2,67-5,0) lapsen arviot 3-portaisia (mahdolliset arvot 1-3). Sekä opettajat että lapset ovat arvioineet myös lapsen mahdollisia erityisiä kielellisiä vaikeuksia. Sanastollisia taitoja on lisäksi arvioitu erillisellä sanastotestillä, joka mittaa sanaston reseptiivistä ja produktiivista sanastonhallintaa eri yleisyystasoilla. ${ }^{4}$

\subsection{Leksikaalisen diversiteetin mittari}

Leksikaalisen diversiteetin arvioinnissa käytetyissä mittareissa on sekä yhteneväisyyksiä että eroja. Lähes kaikki mittarit rakentuvat tavalla tai toisella tarkasteltavan tekstin eri lekseemien ja saneiden suhteen varaan ja yksinkertaisimmillaan vain siihen kuten paljon käytetty TTR eli type-token-ratio (eri sanojen määrä jaettuna saneiden määrällä). TTR-pohjaiset mittarit ovat kuitenkin herkkiä verrattavien tekstien tai tekstiaineistojen kokoeroille ja siten epäluotettavia heterogeenisessa aineistossa. ${ }^{5}$ Sen takia on pyritty yhä tarkempien ja tekstipituuden vaihtelun paremmin sietävien mittareiden kehittelyyn (esim. D: Malvern \& Richards 1997; MTLD: McCarthy 2005; McCarthy \& Jarvis 2007) sekä näiden mittarien vertailevaan validiointiin. ${ }^{6}$

Tässä tutkimuksessa leksikaalisen diversiteetin mittariksi valittiin sama SOP-indeksi (sums of probabilities), jota on käytetty myös aiemmin tehdyssä kirjoitettujen kertomusten leksikaalisen diversiteetin arvioinnissa (Honko 2013). SOP:n Excel-version etuna on pidetty tarkkuutta: aineisto on analyysissa mukana kokonaisuudessaan. SOP pohjautuu Malvernin ja Richardsin kehittä-

$4 \quad$ Ks. yksityiskohtaisempi selostus sekä taustatietolomakkeessa kysytyistä tiedoista että sanastotestistä Honko 2013.

5 Pitkissä teksteissä sanatoisteisuus on yleensä luonnostaan lyhyitä suurempi, sillä jo sanatoisteisuuden pysyminen tasaisena edellyttäisi jatkuvasti uusien sanojen lisäämistä tekstiin samassa suhteessa kokonaissanemäärän lisääntymisen kanssa (Malvern ym. 2004: 124).

6 Jarvis 2002; Malvern \& Richards 2002; Koizumi \& In'Nami 2012; Deboer 2014; Choi \& Jeong 2016. 
mään vocd-instrumenttiin, jonka tuottamaa D-arvoa (D-indeksiä) versioineen on hyödynnetty suurimmassa osassa 2000-luvun taitteessa leksikaalista diversiteettiä tarkastelleista tutkimuksista (ks. tarkemmin Malvern \& Richards 1997, 2002; McKee ym. 2000; Malvern ym. 2004; Durán ym. 2004). SOP, kuten D:kin, mahdollistaa hyvinkin erimittaisten tekstien vertaamisen ( $\mathrm{mm}$. McCarthy \& Jarvis 2007: 460). ${ }^{7}$ SOP-indeksin saamiseksi tekstin kullekin eri sanalle lasketaan esiintymistodennäköisyys valitun teoreettisen otoskoon tai otoskokojen avulla ja analyysin tulos ilmoitetaan kaikkien todennäköisyyksien summana.

Sadutusaineiston tarkastelussa teoreettiseksi otoskooksi asetettiin verrokkitutkimuksen kirjoitettujen tekstien aineistoa vastaten 42 tekstisanaa. (Teoreettisen otoskoon määrittymisestä ja SOP:n sekä vocD:n vertailusta ks. myös Honko 2013: 175-178.) Excel-taulukon (liite 2) esimerkki tarkentaa SOPindeksin laskentaperiaatteen. SOP laskettiin erikseen jokaiselle sadutuskertomukselle SOP-riviarvojen summana. SOP-riviarvo puolestaan on määritelty tekstinäytteen jokaiselle leksikaaliselle yksikölle eli eri sanalle. SOP-riviarvo $(p(F>0))$ kertoo todennäköisyyden, jolla kyseinen leksikaalinen yksikkö esiintyisi vähintään kerran teoreettisen otoskoon mittaisessa kyseisen tekstin näytteessä. Pitkässä tekstissä yksittäiset SOP-riviarvot ovat suhteellisen pieniä mutta yhteenlaskettavia arvoja saadaan enemmän. Liitteessä 2 on esitetty aineiston runsaimman ( $\mathrm{SOP} \approx 34,61$ ) sekä vähäisimmän (SOP $\approx 10,60$ ) leksikaalisen diversiteetin tekstien SOP-laskentataulukot. Jälkimmäisen esimerkin leksikaalinen diversiteetti on tutkitussa aineistossa kuitenkin poikkeuksellisen vähäinen (seuraavaksi pienin SOP-arvo on 21,24).

\subsection{Tilastolliset analyysit ja hajonta-/sirontakuviot}

Muuttujan arvojen normaalijakautuneisuuden testaamiseen on käytetty Shapiro-Wilkin testiä ja vertailtavien otosten varianssien yhtäsuuruuden testaamiseen F-testiä ( $F$ test to compare two variances). SOP-arvojen jakautuminen aineistossa ei noudata normaalijakaumaa (Shapiro-Wilk, $p<0,001$ ) vaan vinoutuu hieman oikealle, ja lisäksi vertailtavien otosten (kuten puhutun ja kirjoitetun kertomusaineiston) SOP-arvojen varianssien yhtäsuuruus ei toteudu (ratio of variances $\approx 0,049, p<0,001$ ). Siksi analyyseissa on käytetty epäparametrisiä menetelmiä.

Koska parametristen testien edellytykset eivät ole voimassa, muuttujien arvojen (lineaarista) riippuvuutta on tutkittu Spearmanin järjestyskorrelaatiolla. Eri otosten muuttujan arvojen vertailussa, kuten puhutun ja kirjoitetun aineiston SOP-arvojen vertailussa on käytetty Mann Whitneyn U-testiä.

Lupaavina mittareina on pidetty myös tasapitkien tekstikatkelmien analysointiin perustuvaa MSTTR-indeksiä sekä TTR:n vakiointiin perustuvaa MTLD-indeksiä, joilla kuitenkin on omat rajoituksensa ja joiden käyttäminen ei tässä tutkimuksessa olisi mahdollistanut vertailua kirjoitettujen kertomusten verrokkiaineistoon (ks. tarkemmin esim. Jarvis 2013a: 94). 
Luokiteltujen muuttujan arvojen vertailuun perustuvassa testauksessa (SOParvojen jakaumien vertailu) on käytetty khiin neliö -testiä.

Tilastollisten analyysien merkitsevyystasot on asetettu seuraavasti: $p \leq 0,05=$ tilastollisesti melkein merkitsevä, $p \leq 0,01=$ tilastollisesti merkitsevä, $p \leq 0,001$ tilastollisesti erittäin merkitsevä. (Ts. virheen todennäköisyys nollahypoteesin kumoamisessa on asetetuilla merkitsevyystasoilla korkeintaan $5 \%, 1 \%$ ja $0,1 \%$.) Tilastollisten analyysien ohella muuttujien välisiä suhteita on systemaattisesti arvioitu myös tarkastelemalla hajonta-/sirontakuvioita, jotka voivat paljastaa tarkasteltavien muuttujien epälineaarisen yhteyden ja viitata kompleksisiin, usean muuttujan yhteisvaikutuksesta muodostuviin riippuvuussuhteisiin aineistossa. Vain pieni osa kuvioista on kuitenkin tilan säästämiseksi nostettu artikkeliin.

\section{Tulokset}

Analyysiosio jakautuu kolmeen alalukuun. Ensimmäisessä luvussa käsitellään modaliteetin yhteyttä kertomuksen leksikaaliseen diversiteettiin ja verrataan toisiinsa lasten puhumalla ja kirjoittamalla tuottamien kertomusten leksikaalista diversiteettiä. ${ }^{8}$ Toisessa alaluvussa tarkastellaan yksilöllisten tekijöiden yhteyttä puhuttujen kertomusten leksikaaliseen diversiteettiin. Keskeisiä vertailumuuttujia on viisi: sadutettavan lapsen sanastolliset taidot, yleinen kielitaitotaso, kielitausta (S1/S2), sukupuoli sekä ikä. Aikuisen läsnäolo sadutusvuorovaikutuksessa on lähtökohtaisesti kiinteämpi kuin pelkkään alkuohjeistukseen perustuvassa kirjoittamistilanteessa, mikä saattaa vaikuttaa sadutettavan lapsen käyttämiin kielellisiin ilmauksiin ja sitä kautta leksikaaliseen diversiteettiin. Siksi kolmannessa analyysiluvussa tarkastellaan tutkijan puheesta kierrätetyn sanaston mahdollista vaikutusta puhuttujen kertomusten leksikaaliseen diversiteettiin.

\subsection{Modaliteetin vaikutus leksikaaliseen diversiteettiin}

Vaikka puheen ja kirjoituksen erot ovat sähköisen viestinnän myötä kaventuneet, kirjoitettu teksti on usein puhetta prosessoidumpaa ja sen leksikaalinen diversiteetti on todettu puhetta runsaammaksi (ks. Strömqvist ym. 2002; Kuiken \& Vedder 2012: 368). Myös sadutusaineistossa puhutun kielen keskimääräinen leksikaalinen diversiteetti on jonkin verran kirjoitettujen kertomusten verokkiaineistoa vähäisempi (taulukko 4 ja liite 3). Ero on tilastollisesti erittäin merkitsevä (Mann Whitneyn U-testi, $\mathrm{W}=108, \mathrm{p}<0,001$ ).

Kirjoitetun kielen aineistoa koskevat tulokset on julkaistu aiemmin osana väitöstutkimustani (Honko 2013), jossa tutkimusasetelma (kertomisen ohjeistus, aineiston käsittely- ja analysointitapa) oli modaliteettia lukuun ottamatta sama kuin nyt analysoitavassa sadutusaineistossa. 
TAULUKKO 4. Leksikaalisen diversiteetin SOP-jakauma.

\begin{tabular}{lrrrrr}
\hline & min. & maks. & ka & kh & md \\
\hline sadutusaineisto $(n=99)$ & 11,00 & 34,61 & 28,96 & 2,94 & 29,43 \\
ikäverrokkien kirjoitelmat $(n=239)$ & 20,48 & 38,37 & 30,22 & 2,88 & 30,46 \\
kirjoitelmat, reaaliseurata $(n=7)$ & 24,06 & 32,27 & 28,53 & 2,74 & 28,52 \\
\hline
\end{tabular}

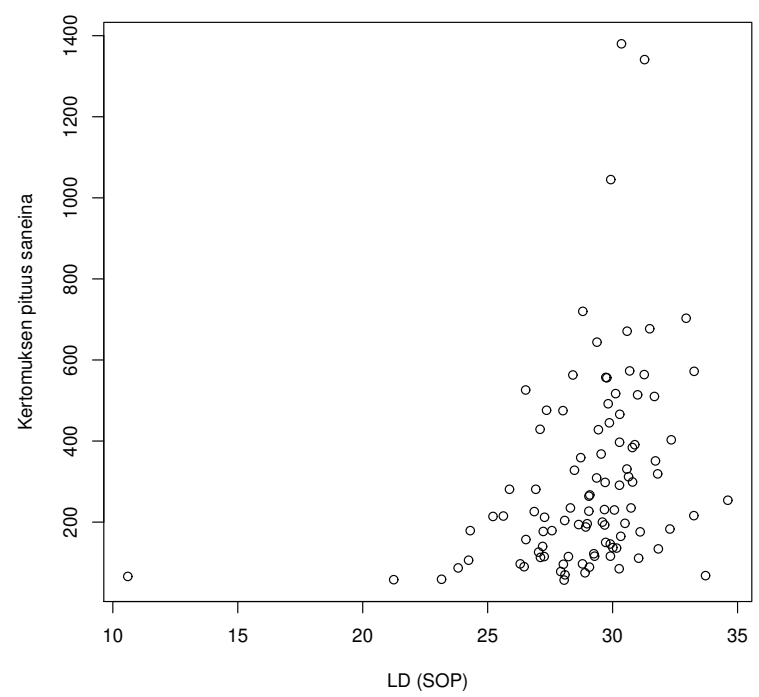

KUVIO 1. Kertomuksen leksikaalisen diversiteetin suhde sen kokonaissanamäärään.

Seitsemältä lapselta on käytettävissä sekä sadutusaineisto että saman lukukauden aikana kirjoitettu kertomus. Aineisto on hyvin pieni, mutta suuntaaantava korrelaatio puhutun ja kirjoitetun kertomustekstin yksilöllisessä leksikaalisessa diversiteetissä on korkea ja tilastollisesti melkein merkitsevä: $r=0,821, p=0,023, n=7$ (käytössä Spearmanin järjestyskorrelaatioanalyysi rS). Tämä tarkoittaa, että leksikaalisen diversiteetin yksilöllinen taso näiden puhujien joukossa on suhteellisen pysyvä modaliteetista toiseen siirryttäessä. Jatkossa ilmiön tarkasteluun tarvittaisiin kuitenkin suurempi aineisto.

Puheaineistossa leksikaalisen diversiteetin ja kokonaissanemäärän välillä on tilastollisesti merkitsevä mutta matala korrelatiivinen yhteys ( $r S=0,422$, saneet, $p<0,001$ ). Kirjoitetuissa teksteissä leksikaalisen diversiteetin ja kokonaissanemäärän välillä on alaluokilla havaittu ainoastaan heikko positiivinen yhteys (Honko 2013: 378-380). Puheaineistossa leksikaalisella diversiteetillä on yhteys myös sadutuksen eri sanojen määrään ( $r S=0,555, p<0,001)$. Korrelaatioanalyysin tulos ja sirontakuvio (kuvio 1) kertovat, että leksikaalinen 
diversiteetti ei kuitenkaan ole kokonaissanamäärän funktio: hyvin eripituiset kertomukset ovat saaneet suurita diversiteettiarvoja.

\subsection{Yksilöllisten tekijöiden vaikutus leksikaaliseen diversiteettiin}

a) sanastolliset taidot Sanastollisia taitoja on arvioitu strukturoidulla testillä (ST), joka mittaa sekä produktiivista että reseptiivistä osaamista. Lisäksi lapsen opettajalta (S1/S2) on pyydetty holistinen arvio sanastollisista taidoista.

Sadutusaineistossa leksikaalinen diversiteetti ja sanastotestillä arvioidut sanastolliset taidot eivät korreloi ( $r S=0,146, p=0,1714, n=89)$, eivät myöskään pelkästään produktiivis- tai reseptiivispainotteisten tehtävien avulla arvioituna. Sirontakuvion perusteella muuttujien välillä ei ole muutakaan säännöllistä yhteyttä. Leksikaalisella diversiteetillä on tosin tilastollisesti melkein merkitsevä yhteys opettajan antamaan holistiseen 5-portaiseen arvioon lapsen sanastollisista taidoista ( $r S=0,349, p=0,025, n=41)$. Korrelaatiokertoimen arvo on kuitenkin jälleen niin matala, että yksilötason arvioinnin kannalta yhteyttä ei voi pitää merkityksellisenä.

Kirjoitelmakorpuksesta laskettu kertomuksen leksikaalinen diversiteetti sen sijaan korreloi kaikilla vuosiluokilla kirjoittajan sanastollisiin taitoihin (ST). Korrelatiivinen yhteys on vain kohtalainen ( $r S=0,433-0,537)$ mutta suurehkossa ryhmässä tilastollisesti erittäin merkitsevä $(p<0,001)$ (Honko 2013: 383). Myös yhteys opettajan arvioimaan kielitaidon yleistasoon (sanastollisen taidon, kirjoitustaidon ja puhetaidon holististen arvioiden indeksi) on tilastollisesti merkitsevä, mutta muuttujien selitysvoima toisiinsa nähden hyvin alhainen ( $r S=0,302, p=0,002, n=104)$.

Kiinnostavaa on, että sadutetun sanaston leksikaalisella diversiteetillä löytyy yllättävä yhteys sanastolliseen osaamiseen 3 vuotta myöhemmin $(r S=0,419, p=0,008, n=39)$. Käytetty testi (ST2) on mukautettu uuteen ikätasoon (5.-6. luokka) ja siinä painottuu aiempaa testiä (ST) enemmän sanavaraston laajuuden arviointi. Perusperiaatteet ja erottelukyky ovat kuitenkin samat (ks. Honko 2013). Alaluokilla lasten erot tekstitaidoissa voivat kuitenkin vaikuttaa sanastotestin tulokseen, mikä selittäisi yhteyden puuttumista juuri alaluokilla.

b) yleinen kielitaitotaso S2-ryhmässä sadutusaineistossa leksikaalisella diversiteetillä on heikosti merkitsevä matala korrelatiivinen yhteys sekä opettajan ( $r S=0,32, p=0,038, n=41)$ että lapsen itsensä arvioimaan kielitaidon yleistasoon ( $r S=0,34, p=0,033, n=41$ ). Yhteyttä sen sijaan ei löydy muihin pyydettyihin taustatietoihin: edelliseen suomen kielen todistusarvosanaan (numeerinen tai numeeristettu sanallinen arvio, $n=28$ ), opettajan tai lapsen arvioimiin kielellisiin erityisvaikeuksiin (summamuuttuja $n=40, n=41$ ) tai Suomessa asumisen kestoon $(n=69)$. 


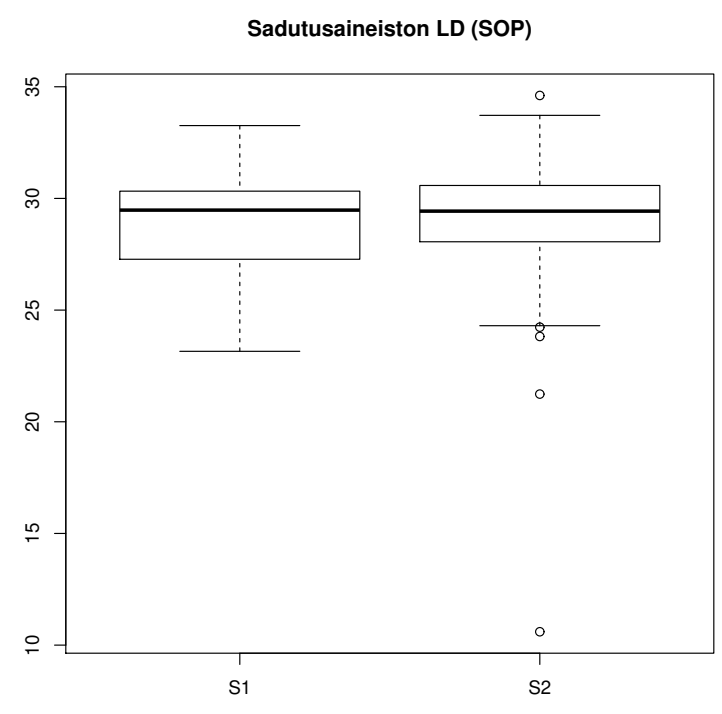

KUVIO 2. Kielitaustan yhteys sadutetun kertomuksen leksikaaliseen diversiteettiin.

Kielitaidon yleistason yhteys kirjoitettujen kertomusten leksikaaliseen diversiteettiin on opettajan arvioimana merkitsevä mutta heikompi kuin yhteys erillisellä testillä (ST) mitattuun sanastonhallintaan (Honko 2013). Lapsen itsearvioinnin tulos sen sijaan ei ole yhteydessä kirjoitetun kertomuksen leksikaaliseen diversiteettiin. Lisäksi kielitaidon yleisarvioinnin karkeana kuvaajana on käytetty edellistä suomen kielen todistusarvosanaa (vaihteluväli 69) ja opettajan sekä lapsen arvioimien kielellisten erityisvaikeuksien määrää (vaihteluväli 0-9 ja 0-12) sekä maassaolon kestoa (2-11 vuotta). Maassaolon keston yhteys kielitaitoon tosin tiedetään tutkitussa ryhmässä kompleksiseksi (Honko 2013).

c) ensikieli Sadutusaineistossa leksikaalisessa diversiteetissä ei ilmene eroa kieliryhmien välillä (Mann-Whitney $W=1009, p=0,8461$, ks. kuvio 2). Eroa S1ja S2-oppilaiden leksikaalisessa diversiteetissä ei ole myöskään erikseen tyttöjen ja poikien tai tois- ja kolmasluokkalaisten sadutuksista arvioituna ( $W=276$, $p=0,8047 ; W=233, p=0,9088 ; W=232, p=0,1249 ; W=210, p=0,1189)$. Hajonta on S2-aineistossa hieman suurempi, ja ylin neljännes sijoittuu hieman ensikielisten ryhmää korkeammalle tasolle. Tulosta ei selitä ero tuottamisen runsaudessa, sillä sadutuksen sane- tai sanamäärä eivät eroa kieliryhmittäin.

Kirjoitelma-aineistossa S1-oppilaiden keskimääräinen leksikaalinen diversiteetti sen sijaan on ryhmätasolla kaikilla vuosiluokilla S2-oppilaiden tekstien diversiteettiä runsaampi (Honko 2013). Tasavälein ryhmitettyjen SOP-arvojen 
ristiintaulukointi ja tarkastelu khiin neliö -testillä osoittavat, että eniten toisistaan poikkeavat jakauman ääripäät: S2-oppijoiden teksteissä on suhteessa enemmän vähäisen ja vähemmän runsaan leksikaalisen diversiteetin kertomuksia. Tähän tulokseen suhteutettuna on yllättävää, että puheaineistossa kieliryhmien leksikaalisessa diversiteetissä ei ilmene eroa.

d) sukupuoli Sadutusaineistossa poikien leksikaalisen diversiteetin mediaani on hieman tyttöjen leksikaalisen diversiteetin mediaania suurempi, mutta ero ryhmien välillä ei ole tilastollisesti merkitsevä (Mann-Whitney W=1494, $\mathrm{p}=0,059)$. Tätä selittää poikien aineiston suurempi hajonta: poikien aineistossa ovat sekä pienimmät että suurimmat diversiteettiarvot (liite 3).

Alakoululaisten kirjoittamistutkimuksissa tyttöjen kirjoittamien tekstien leksikaalinen diversiteetti on havaittu poikien kirjoittamien tekstien diversiteettiä runsaammaksi (Honko 2013; ks. myös Saarela 1997). Aikuisten puhutun kielen aineistoista tehtyjen tutkimusten tulokset ovat kuitenkin ristiriitaiset: Dewaelen ja Pavlenkon (2003: 134) tutkimuksessa naisten käyttämä sanasto on miesten sanastoa vaihtelevampaa, Singhin (2001: 260-261) ja Härnqvistin, Christiansonin, Ridingsin ja Tingsellin (2003: 191) tutkimuksessa tulos on päinvastainen.

e) ikä Tyypillisessä kielenkehityksessä oppijan leksikko karttuu ja syvenee kouluvuosina huimasti, mikä heijastuu spontaanin tuottamisen sanastoon (Berman 2007; Pajunen 2012). Aiemman tutkimuksen perusteella leksikaalinen diversiteetti, myös SOP, erottelee kielitaidoltaan eritasoisia puhujia ja kirjoittajia paremmin varhaisemmassa kielenkehityksen ja kirjoitustaidon vaiheessa (Vermeer 2000; Jarvis 2002; Honko 2013: 370-372).

Tois- ja kolmasluokkalaisten sadutusaineistossa SOP-diversiteettiarvot eivät poikkea toisistaan (Mann-Whitney $W=1149, p=0,6019$ ). Ikäluokittain havaintoja ei ole riittävästi kaikissa luokissa (7-11 vuotta) Mann Whitneyn Utestin suorittamiseen, mutta Spearmanin järjestyskorrelaatioanalyysi ja sirontakuvio paljastavat, että iän ja leksikaalisen diversiteetin välillä ei tutkitussa aineistossa ole korrelatiivista ( $r S=0,088)$ tai muutakaan havaittavaa säännönmukaista yhteyttä.

Kirjoitetuissa kertomuksissa leksikaalisen diversiteetin kehitys sen sijaan on kaikissa alaryhmissä vielä alakouluvaiheessa nousujohteista vaikkakaan ei täysin lineaarista luokkatasolta toiselle. Ero vuosiluokkien 2-3 välillä on ttestillä mitattuna tilastollisesti erittäin merkitsevä. (Honko 2013: 365-366.)

\subsection{Kierrätetyn sanaston vaikutus leksikaaliseen diversiteettiin}

Ne lapset, joiden sanastolliset taidot opettaja on arvioinut parhaiksi, ovat myös käyttäneet sadutuksessa verrattain vaihtelevaa sanastoa. Toiseen suun- 


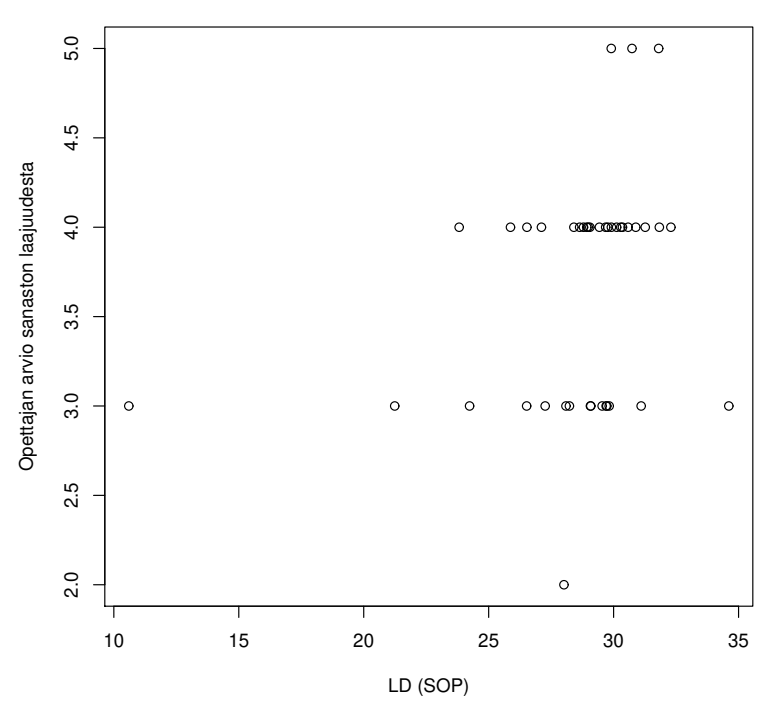

KUVIO 3. Opettajan arvioiman sanavaraston yhteys sadutetun kertomuksen leksikaaliseen diversiteettiin.

taan yhteys ei kuitenkaan päde (kuvio 3). Tulos saattaa tarkoittaa, että joidenkin oppilaiden sanastollinen osaaminen jää arjessa opettajalta piiloon ja todentamatta myös sanastotestissä (ks. luku 4.1 kohta b). On kuitenkin mahdollista, että sadutustilanteet eivät ole keskenään täysin vertailukelpoisia. Yksi selitys voisi piillä siinä, että heikompaa sanastonhallintaa on vuorovaikutustilanteessa mahdollista kielellisesti kompensoida vuorovaikutuskumppanilta kierrätetyllä sanastolla.

Toisen kielenkäyttäjän tekstien käyttäminen lähteenä voi kasvattaa leksikaalista diversiteettiä, mikä on aikaisemmassa tutkimuksessa todennettu kirjoitetun kielen kontekstissa (Gebril \& Plakans 2016). Sadutusaineistossa tämä tarkoittaa sitä, että sadutettu lapsi voi omassa puheessaan kierrättää paitsi sadutustuokion ulkopuolella oppimiaan sanoja myös sen aikana aikuisen puheesta poimimaansa kielenainesta - kuten sanastoa. Sadutettujen kertomustekstien leksikaalisen diversiteetin ja kielitaustan sekä luokkatason ja muilla menetelmillä arvioidun sanastollisen osaamisen välisen riippuvuuden puuttuminen (luku 4.2) voisikin selittyä sillä, että sanastollisilta taidoiltaan heikoimmat lapset ovat vuorovaikutustilanteessa aktiivisimpia sanaston kierrättäjiä. Sen takia on tarpeen tarkastella erikseen sanaston mahdollista kierrättämistä sadutusaineistossa.

Jo sadutustuokioista kirjoitettujen keskustelulitteraattien alustava laadullinen tarkastelu osoittaa, että saduttajan rooli uuden sanaston tuojana on tutkitussa vuorovaikutusaineistossa hyvin vähäinen: alkuorientaation jälkeen 
pääosa saduttajan vuoroista koostuu pelkästä dialogipartikkelista kuten $\mathrm{mm}$, joo, nii (ks. myös liite 1) tai lyhyestä kehotuksesta tai kysymyksestä (kerro lisää, mitä sitten tapahtui?), johon lapsi reagoi esimerkiksi jatkamalla kertomista. Silloinkin, kun se olisi mahdollista, lapsi kierrättää aikuisen puheen kautta tarjoutuvaa sanastoa omaan puheeseensa vain harvoin. Saduttajalle (S) sen sijaan on tyypillisempää toistaa sanoja ja laajempia ilmauksia lapsen (L) puheesta (esimerkki 1).

(1)

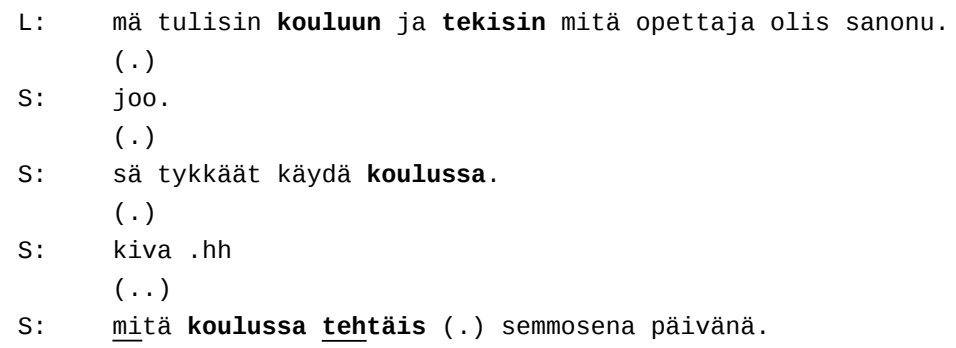

Saduttajan rooli kielellisenä osallistujana korostuu tilanteissa, joissa lapsi tarvitsee tukea: aikuinen toistaa lapsen puhetta, toisinaan myös kokoaa tai jatkaa lapsen vuoroja tai esittää lisäkerrontaan rohkaisevia kysymyksiä (esimerkki 2).

(2)

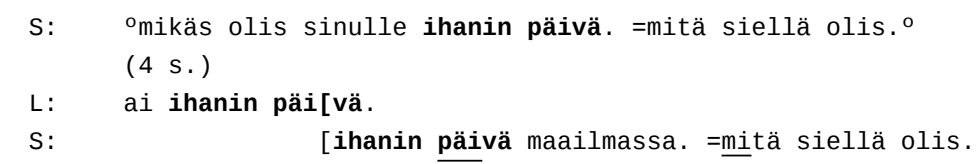

Kierrättämistä oli tarpeellista tutkia myös tarkemmin: sadutustuokioista kirjoitettujen litteraattien avulla etsittiin kaikki sellaiset sisältösanaluokkien sanat, joita lapsi käyttää sadutustuokiossa ensimmäisen kerran vasta aikuisen käytettyä sanaa aiemmin omassa puheessaan. Tarkastelu rajattiin eri diversiteettitasoilta poimittuun 20 kertomuksen otokseen ( $20 \%$ koko aineistosta). Analyysissa huomioitiin sanan kaikki esiintymiskontekstit: esiintyminen osana yhdyssanoja ja erilaisia monisanaisia konstruktioita joko välittömästi aikuisen vuoron jälkeen tai vasta myöhemmin sadutustuokion aikana.

Näin laskettuna kierrätettyjä sanoja esiintyy lapsen puhutuissa kertomuksissa keskimäärin vähemmän kuin yksi esiintymä sadutusta kohti (vaihteluväli 0-5). Kierrätettyjen eri sanojen määrä jää vielä pienemmäksi (0-3). Kahdessatoista eli yli puolessa (60\%) tarkastelluista sadutustuokioista ei esiinny lainkaan aikuisen vuoroista kierrätettyä sanastoa. Havaintojen perusteella sanojen kierrättäminen aikuisen puheesta ei selitä aiemmissa luvuissa esitettyjä tuloksia. 
Tuloksen voi olettaa olevan vahvasti sidoksissa sadutusvuorovaikutuksen luonteeseen ja heijastavan sadutusmetodin ohjeistusta: saduttajan ei kuulu tarjota lapselle kerronnan sisältöjä (Karlsson 2014). Myös tutkitussa aineistossa saduttajan puhe on karsittua; vuorot ovat lyhyitä ja rakentuvat niukan, pitkälti jo tehtävänannossa tai lapsen omissa ilmauksissaan käyttämän sanaston varaan. Vuorottelurakenteen tarkempi tarkastelu kuitenkin paljastaa, että sillä saattaa olla muunlaisia - leksikaaliseen diversiteettiin heijastuvia - vaikutuksia sadutettavan tuottamaan puheeseen. Sadutustuokion aikana eniten tukea tarvitsevien lasten vuorot ovat yleensä hyvin lyhyitä lausekkeita, joista puuttuu vapaalle kerronnalle tyypillinen sisällöllinen ja rakenteellinen yhtenäisyys (liite 4). Pidempiin yhtenäisiin vuoroihin perustuvassa kerronnassa sen sijaan yhtenäisyyttä luodaan muun muassa sisäisiä viittaussuhteita rakentavalla leksikaalisella toistolla, jolla voi olla myös puheen prosessointiin ja sadustustuokion vuorojäsennyksen muokkaamiseen liittyviä tehtäviä. Vuorojäsennyksen ja vuorojen rakenteen vaikutusta leksikaaliseen diversiteettiin ei ole aiemmin tutkittu, mutta systemaattinen tarkastelu on kiistatta tarpeen, mikäli puhutun kielen leksikaalista diversiteettiä jatkossakin tutkitaan keskusteluvuorovaikutusaineistoista.

\section{Tulosten koonti ja pohdinta}

Tutkimuksen tehtävänä oli selvittää, onko a) lasten sadutettujen kertomusten leksikaalisessa diversiteetissä systemaattisia eroja eri modaliteettien tai puhujaryhmien välillä ja b) voisiko leksikaalinen diversiteetti toimia kehityksellisenä mittarina vastaavia aineistoja analysoitaessa. Kirjoitetun kielen leksikaalinen diversiteetti osoittautui puheen diversiteettiä runsaammaksi, mikä tukee aiempien tutkimusten tuloksia. Myös yksilötasolla modaliteettien välinen yhteys on tarkastellussa pienessä ryhmässä havaittavissa. Kieliryhmien (L1/L2), tyttöjen ja poikien tai tois- ja kolmasluokkalaisten välillä leksikaalisessa diversiteetissä ei kuitenkaan ilmennyt eroja, ja sekä kielitaidon yleistason että sanaston hallinnan yleistason (testisuoritus tai opettajan arvio) yhteys leksikaaliseen diversiteettiin osoittautui epälineaariseksi ja heikoksi. Sadutettujen kertomusten leksikaalisella diversiteetillä ei tarkastellussa aineistossa ollut yhteyttä myöskään lapsen edelliseen suomen kielen kouluarvosanaan, opettajan listaamien kielellisten erityisvaikeuksien määrään tai Suomessa asumisen kestoon (S2-ryhmä). Tulosten perusteella leksikaalista diversiteettiä (SOP) ei voi pitää riittävän tarkkana menetelmänä yksilötason kielitaidon tai tarkemmin sanastollisten taitojen arvioimiseen puhevuorovaikutuksessa.

Myös aiemman puhevuorovaikutuksesta tehdyn tutkimuksen tulokset ovat jättäneet leksikaalisen diversiteetin arviointikäyttöön varauksia. Sadutustuokioiden vuorojäsennyksen laadullinen tarkastelu osoittaa, että eri diversi- 
teettitasojen tekstit saattavat poiketa toistaan laadullisesti muutoinkin kuin sanaston osalta. Vaikka ryhmätasolla runsas leksikaalinen diversiteetti yhdistyykin tuottamisen runsauteen, yhteys ei ole lineaarinen: Runsaan leksikaalisen diversiteetin kertomukset näyttävät usein koostuvan lyhyistä ja rakenteeltaan yksinkertaisista vuoroista, jotka on tuotettu ikään kuin reaktiona saduttajan rohkaisevaan viestintään, vähäisen diversiteetin kertomuksissa puolestaan on paljon pitkiä, spontaanisti tuotettuja vuoroja. Yksilötasolla kertomisen niukkuus voi siksi selittää runsasta leksikaalista diversiteettiä ja yhtenäisen, vuolaan kertomuksen leksikaalinen diversiteetti puolestaan olla vähäinen. Vaikka sadun kertomisessa on monologimaisia piirteitä, sadutustuokio on kuitenkin vuorovaikutustilanne ja lapselle mahdollisesti myös uudenlainen ja jännittävä tilanne. Puhevuorovaikutukseen osallistumiseen sadutuksessa tarvitaan sanastollisen osaamisen lisäksi paljon muutakin - tehtävänantoon reagoimisen lisäksi esimerkiksi avoimuutta ja uskallusta sekä henkilökohtainen tarve osallisuuteen. Siksi sadutettu puhe väistämättä antaa kapean kuvan sadutettavan kokonaiskielitaidosta.

Tämän tutkimuksen perusteella näyttää siltä, että aikuisen tuen suora vaikutus leksikaaliseen diversiteettiin sadutustuokioissa on kuitenkin hyvin pieni: lasten kerronnassa esiintyy hyvin vähän aikuiselta kierrätettyjä sanoja, mikä johtuu osittain aikuisen pelkistetyistä vuoroista (Honko 2017). Koska saduttajan vuoroista kierrätettyä sanastoa esiintyy vähän, kierrättämisen vaikutus leksikaaliseen diversiteettiin on minimaalinen. Tukea tarvitsevien lasten niukka kerronta ja lyhyet vuorot sen sijaan johtavat usein välillisesti suhteellisen runsaaseen diversiteettiin, kun esimerkiksi tekstiä sidostava leksikaalinen toisto ja funktiosanojen käyttö on niukkaa.

Oletuksia siitä, että leksikaalinen diversiteetti voisi toimia kehityksellisenä mittarina ja jopa diagnostisena työkaluna on kritisoitu muun muassa kielenoppimisprosessin yksinkertaistamisesta ja kielenkäytön tilanteisuuden sivuuttamisesta: Kaikki sanastollinen osaaminen ei esimerkiksi ole luonteeltaan määrällistä eikä siis heijastu sanavaraston kasvuna. Kaikissa tilanteissa ja tekstilajeissa ei myöskään tarvitse tai edes kannata käyttää samanlaista kieltä ja siten myöskään samalla tavalla varioivaa sanastoa. On selvää, että esimerkiksi ääneen prosessointi sanoja toistamalla yksittäistapauksissa laskee leksikaalista diversiteettiä (mä olin- mä- mä- mä oon aina nii tehny). Lisäksi puhutussa kielessä leksikaalisen tiiviyden haittapuolet korostuvat, minkä vuoksi hyvin runsas leksikaalinen diversiteetti ei aina ole vuorovaikutuksessa etu (ks. myös Broeder ym. 1993: 149). Kuten tässä artikkelissa aiemmin esillä olleiden tutkimusten perusteella voidaan todeta, pidemmällä edenneet kielenoppijat kuitenkin tyypillisesti toistavat sanastoa vähemmän ja heidän tuottamissaan teksteissä leksikaalinen diversiteetti on suhteessa runsaampi kuin verrokkiryhmissä (ei-äidinkieliset tai alkeistason oppijat). Heterogeenisissa aineistossa leksikaalinen diversiteetti voikin toimia suuntaa-antavana kielitaidon mittari- 
na, mikäli aineistoa on riittävästi ja se on tuotettu yhdenmukaisilla tavoilla. Jatkossa tarkastelua on kuitenkin syvennettävä laajemmalla aineistolla ja tarpeen mukaan myös monimuuttuja-analyysia käyttäen sen selvittämiseksi, millaisia kerrannaisvaikutuksia tai mahdollisesti myös toisensa pois rajaavia vaikutuksia eri muuttujilla on suhteessa leksikaaliseen diversiteettiin.

Leksikaalisen diversiteetin menetelmällisessä tutkimuksessa on tyypillisesti keskitytty siihen, kuinka hyvin käytetty mittari ennustaa kielellistä suoriutumista verrattuna johonkin toisentyyppiseen mittariin. Oletuksena on ollut, että leksikaalisen diversiteetin määritelmään joka tapauksessa kuuluu ainakin sanojen valikoiman laajuus (range) ja vaihtelu (variety) (McCarthy \& Jarvis 2007: 459). Aivan viime vuosina on kuitenkin havahduttu huomaamaan, että edes diversiteettimittarin tilastollisesti merkitsevä erottelukyky ei takaa sen käytettävyyttä. Samalla on ryhdytty tarkemmin perehtymään leksikaaliseen diversiteettiin tutkittavana ilmiönä, toisin sanoen tutkimaan, mistä - ja erityisesti mistä muusta kuin sanatoisteisuudesta tai tarkasteltavan tekstin kokonaissanamäärästä - leksikaalinen diversiteetti mahdollisesti koostuu (Jarvis 2013b).

Näyttää siltä, että leksikaalisen diversiteetin määritteleminen pelkästään tekstin sisältämien sanojen vaihteluksi on pelkistys, joka jättää huomiotta muun muassa sanojen ominaislaadun. Tämä ja monet muut seikat saattavat kuitenkin olennaisesti vaikuttaa tekstin vastaanottajan kokemukseen leksikaalisesta diversiteetistä, sanojen määrän ja vaihtelevuuden ohella (Crossley ym. 2011a,b; Jarvis 2013b). Tämän tutkimuksen perusteella leksikaalisen diversiteetin mahdollisissa jatkotutkimuksissa vaaditaan aiemman diversiteettitutkimuksen perinteestä irrottautumista ja kehitystyötä kahdella tavalla: diversiteetin määrittelyssä ja puhevuorovaikutuksen ominaislaadun huomioon ottamisessa.

\section{Kiitokset}

Tutkimus on osa myöhemmän kielenkehityksen tarkasteluun keskittyvää hanketta (ks. esim. Pajunen 2012). Kiitän Tampereen yliopistoa, Tampereen Yliopiston Tukisäätiötä, Jyväskylän yliopistoa, artikkelin kahta nimetöntä arvioijaa sekä aivan erityisesti tutkimusavustaja Minna Bogdanoffia tuesta tämän tutkimusartikkelin syntyprosessin eri vaiheissa aineistonkeruusta viimeistelyyn.

\section{Lähteet}

Alderson, J. C. 2005. Diagnosing foreign language proficiency: the interface between learning and assessment. London: Continuum.

Berman, R. 2007. Developing language knowledge and language use across adolescence. Teoksessa E. Hoff \& M. Shatz (toim.) Handbook of language development. London: Blackwell, 346-367. 
Berman, R. \& L. Verhoeven 2002. Cross-linguistic perspectives on the development of text-production abilities: speech and writing. Written Language and Literacy, 5 (1), 1-43.

Bradac, J. J. \& R. Wisegarver 1984. Ascribed status, lexical diversity and accent: determinants of perceived status solidarity, and control of speech style. Journal of Language and Social Psychology, 3 (4), 239-255.

Broeder, P., G. Extra \& R. van Hout 1993. Richness and variety in the developing lexicon. Teoksessa C. Perdue (toim.) Adult language acquisition: crosslinguistic perspectives, volume I: Field methods. Cambridge: Cambridge University Press, 145-232.

Burroughs, E. I. 1991. Lexical diversity in listeners' judgments of children. Perception and Motor Skills, 73 (1), 19-22.

Cain, K., J. Oakhill \& K. Lemmon 2004. Individual differences in the inference of word meanings from context: the influence of reading comprehension, vocabulary knowledge and memory capacity. Journal of Educational Psychology, 96 (4), 671681.

Carroll, J. B. 1938. Diversity of vocabulary and the harmonic series law of wordfrequency distribution. Psychological Record, 2, 379-386.

Castañeda-Jiménez, G. \& S. Jarvis 2014. Exploring lexical diversity in second language Spanish. Teoksessa K. Geeslin (toim.) The handbook of Spanish second language acquisition. Hoboken (N. Y.): Wiley, 498-513.

Choi, W. \& H. Jeong 2016. Finding an appropriate lexical diversity measurement for a small-sized corpus and its application to a comparative study of L2 learners' writings. Multimedia Tools and Applications, 75 (21), 13015-13022.

Crossley, S. A., T. Salsbury \& D. S. McNamara 2011a. Predicting the proficiency level of language learners using lexical indices. Language Testing, 29 (2), 243-263.

Crossley, S. A., T. Salsbury, D. S. McNamara \& S. Jarvis 2011b. What is lexical proficiency? Some answers from computational models of speech data. TESOL Quarterly, 45 (1), 182-193.

Deboer, F. 2014. Evaluating the comparability of two measures of lexical diversity. System, 47, 139-145.

Dewaele, J.-M. \& A. Pavlenko 2003. Productivity and lexical diversity in native and non-native speech: a study of cross-cultural effects. Teoksessa V. J. Cook (toim.) L2 effects on the L1. Clevedon: Multilingual Matters, 120-141.

Dockrell, J. E. \& D. Messer 2004. Lexical acquisition in the early school years. Teoksessa R. Berman (toim.) Language development across childhood and adolescence: psycholinguistic and crosslinguistic perspectives. Amsterdam: John Benjamins, 35-52.

Durán, P., D. Malvern, B. Richards \& N. Chipere 2004. Developmental trends in lexical diversity. Applied Linguistics, 25 (2), 220-242.

Ellis, C., Y. F. Holt \& T. West 2015. Lexical diversity in Parkinson's disease. Journal of Clinical Movement Disorders, 2 (5). DOI: 10.1186/s40734-015-0017-4. https: //www.ncbi.nlm.nih.gov/pmc/articles/PMC4710975/.

Gebril, A. \& L. Plakans 2016. Source-based tasks in academic writing assessment: lexical diversity, textual borrowing and proficiency. Journal of English for Academic Purposes, 24, 78-88. 
Gregori-Signes, C. \& B. Clavel-Arroitia 2015. Analysing lexical density and lexical diversity in university students' written discourse. Procedia Social and Behavioral Sciences, 24 (198), 546-556.

Honko, M. 2013. Alakouluikäisten leksikaalinen tieto ja taito: toisen sukupolven suomi ja S1-verrokit. Acta Universitatis Tamperensis 1865. Tampere: Tampere University Press. http://tampub.uta.fi/handle/10024/94544.

- 2017. Kieli- ja kielitaitokäsitykset tutkivan opettajan kenttäpäiväkirjamerkinnöissä. Puhe ja kieli, 4/2017, 215-238.

Härnqvist, K., U. Christianson, D. Ridings \& J.-G. Tingsell 2003. Vocabulary in interviews as related to respondent characteristics. Computers and the Humanities, 37 (2), 179-204.

ISK 2004 = Hakulinen, A., M. Vilkuna, R. Korhonen, V. Koivisto, T.-R. Heinonen \& I. Alho 2004. Iso suomen kielioppi. Helsinki: Suomalaisen Kirjallisuuden Seura.

Jarvis, S. 2002. Short texts, best-fitting curves and new measures of lexical diversity. Language Testing, 19 (1), 57-84.

- 2013a. Capturing the diversity in lexical diversity. Language Learning, 63 (1), 87106.

- 2013b. Defining and measuring lexical diversity. Teoksessa S. Jarvis \& M. Daller (toim.) Vocabulary knowledge: human ratings and automated measures. Amsterdam: John Benjamins, 13-44.

Johansson, V. 2008. Lexical diversity and lexical density in speech and writing: a developmental perspective. Teoksessa Department of Linguistics and Phonetics Working Papers 53. Lund: Lund University, 61-79. http://journals.lub.lu.se/index. $\mathrm{php} / \mathrm{LWPL} /$ article/view/2273.

Karlsson, L. 2013. Storycrafting method: to share, participate, tell and listen in practice and research. The European Journal of Social \& Behavioural Sciences, Special Volumes VI Design in Mind, 6 (3), 1109-1117.

- 2014. Sadutus: avain osallistavan toimintakulttuuriin. 3. laitos. Jyväskylä: PSkustannus.

Klee, T., S. F. Stokes, A. M.-Y. Wong, P. Fletcher \& W. Gavin 2004. Utterance length and lexical diversity in Cantonese-speaking children with and without specific language impairment. Journal of Speech, Language, and Hearing Research, 47 (6), 13961410.

Koizumi, R. \& Y. In'Nami 2012. Effects of text length on lexical diversity measures: using short texts with less than 200 tokens. System, 40 (4), 554-564.

Kuiken, F. \& I. Vedder 2012. Speaking and writing tasks and their effects on second language performance. Teoksessa S. M. Gass \& A. Mackey (toim.) The Routledge handbook of second language acquisition. London: Taylor ja Francis, 364-377.

Lai, S. \& P. J. Schwanenflugel 2016. Validating the use of "D" for measuring lexical diversity in low-income kindergarten children. Language, Speech, and Hearing Services in Schools, 47 (3), 225-235.

Lervåg, A. \& V. G. Aukrust 2010. Vocabulary knowledge is a critical determinant of the difference in reading comprehension growth between first and second language learners. Journal of Child Psychology and Psychiatry, 51 (5), 612-620.

Malin, E. 2012. Suomi toisena kielenä -oppijoiden sanaston kehittyminen taitotasolta toiselle siirryttäessä. Pro gradu -tutkielma. Jyväskylä: Jyväskylän yliopisto. http: //urn.fi/URN:NBN:fi:jyu-201211223060. 
Malvern, D. \& B. Richards 1997. A new measure of lexical diversity. Teoksessa A. Ryan $\&$ A. Wray (toim.) Evolving models of language: papers from the annual meeting of the British Association of Applied Linguists held at the University of Wales, Swansea, September 1996. Clevedon: Multilingual Matters, 58-71.

- 2002. Investigating accommodation in language proficiency interviews 426 using a new measure of lexical diversity. Language Testing, 19 (1), 85-104.

Malvern, D., B. Richards, N. Chipere \& P. Durán 2004. Lexical diversity and language development: quantification and assessment. Houndmills: Palgrave Macmillan.

McCarthy, P. M. 2005. An assessment of the range and usefulness of lexical diversity measures and the potential of the measure of textual, lexical diversity (MTLD). Väitöskirja. University of Memphis.

McCarthy, P. M. \& S. Jarvis 2007. Vocd: a theoretical and empirical evaluation. Language Testing, 24 (4), 459-488.

McKee, G., D. Malvern \& B. Richards 2000. Measuring vocabulary diversity using dedicated software. Literary and Linguistic Computing, 15 (3), 323-337.

Milton, J. 2009. Measuring second language vocabulary acquisition. Bristol: Multilingual Matters.

Muter, V., C. Hulme, M. J. Snowling \& J. Stevenson 2004. Phonemes, rimes, vocabulary and grammatical skills as foundations of early reading development: evidence from a longitudinal study. Developmental Psychology, 40 (5), 665-681.

Pajunen, A. 2012. Kirjoittamistaitojen kehitys 8-12-vuotiailla: alakoululaisten unelmakirjoitelmat. Virittäjä, 114 (1), 481-501.

Qian, D. D. \& M. Schedl 2004. Evaluation of an in-depth vocabulary knowledge measure for assessing reading performance. Language Testing, 21 (1), 28-52.

Riihelä, M. 1991. Aikakortit: tie lasten ajatteluun. Helsinki: VAPK-kustannus.

- 2013. Suomalaisten pienten lasten ajatuksia heijastava erittäin laaja aineisto kaipaa tutkijoita! http://www.edu.helsinki.fi/lapsetkertovat/lapset/Tutkimus/ tutkimus_aineisto.htm [luettu 30.9. 2017].

Saarela, L. 1997. Peruskoululaisten kirjoitelmien kehittyminen sanastotutkimuksen valossa. Acta Universitatis Ouluensis B Humaniora 25. Oulu: Oulun yliopisto.

Schmid, M. \& S. Jarvis 2014. Lexical access and lexical diversity in first language attrition. Bilingualism: Language and Cognition, 17 (4), 729-748.

Scott, C. M. \& J. Windsor 2000. General language performance measures in spoken and written narrative and expository discourse of school-age children with language learning disabilities. Journal of Speech, Language and Hearing Research, 43 (2), 324-339.

Singh, S. 2001. A pilot study on gender differences in conversational speech on lexical richness measures. Literary and Linguistic Computing, 16 (3), 251-264.

Strömqvist, S., V. Johansson, S. Kriz, H. Ragnarsdóttir, R. Aisenman \& D. Radvid 2002. Toward a cross-linguistic comparison of lexical quanta in speech and writing. Written Language and Literacy, 5 (1), 45-67.

Taimisto, H. 2014. Taitotasolta toiselle: korpuspohjainen tutkielma vironkielisten suomenoppijoiden verbisanaston kehittymisestä. Pro gradu -tutkielma. Suomen kieli, Oulun yliopisto.

Tannenbaum, K. R., J. K. Torgesen \& R. K. Wagner 2006. Relationships between word knowledge and reading comprehension in third-grade children. Scientific Studies of Reading, 10 (4), 381-398. 
Tidball, F. \& J. Treffers-Daller 2007. Exploring measures of vocabulary richness in semispontaneous French speech. Teoksessa H. Daller, J. Milton \& J. Treffers-Daller (toim.) Modelling and assessing vocabulary knowledge. Cambridge: Cambridge University Press, 133-149.

Unsworth, S. 2004. Comparing child L2 development with adult L2 development: how to measure L2 proficiency. Teoksessa B. Haznedar \& E. Gavruseva (toim.) Current trends in child second language acquisition: a generative perspective. Amsterdam: John Benjamins, 301-333.

Watkins, R., D. Kelly \& H. Harbersh 1995. Measuring children's lexical diversity: differentiating typical and impaired language learners. Journal of Speech and Hearing Research, 38 (6), 1349-1355.

Verhoeven, L. 1990. Acquisition of reading in a second language. Reading Research Quarterly, 25 (2), 90-114.

Vermeer, A. 2000. Coming to grips with lexical richness in spontaneous speech data. Language Testing, 17 (1), 65-83.

Wong, A., T. Klee, S. Stokes, P. Fletcher \& L. Leonard 2010. Differentiating Cantonesespeaking preschool children with and without SLI using MLU and lexical diversity. Journal of Speech, Language, and Hearing Research, 53 (3), 794-799.

Wright, H., S. Silverman \& M. Newhoff 2003. Measures of lexical diversity in aphasia. Aphasiology, 17 (5), 443-452.

Yu, G. 2010. Lexical diversity in writing and speaking task performances. Applied Linguistics, 31 (2), 236-259.

Zipf, G. K. 1935. The psycho-biology of language. Boston (Mass.): Houghton-Mifflin.

- 1937. Observations of the possible effect of mental age upon the frequencydistribution of words from the viewpoint of dynamic philology. Journal of Psychology, 4, 239-244. 


\section{Liite 1: Esimerkki sadutustuokiosta (3. Ik tyttö S2)}

01 L: olipa kerran,

$02 \quad$ (.)

$03 \mathrm{~S}: \mathrm{mm}$ ?

$04 \quad($.

05 L: mmh mun perhe?

$06 \mathrm{~S}:=\mathrm{mm}$ ?

07 L: =ja minä?

$08 \mathrm{~S}:=\mathrm{mm}$ ?

09 L: =mentiin matkustelemaan Vietnamii:n,

$10 \quad($.

$11 \mathrm{~S}: \mathrm{mm}$,

$\mathrm{L}:=$ sit me leikittiin siel sit mentiin kirkkoon sit me tutkittiin mu äidin kaa ku mentiin sen kaa .h sie:llä sitte .hh >siel oli< haus-tausjuttuja siel oli hautoja sellassii, (.)

S: $m[m$ ?

L: [sit lähettiin kotiin sit mentiin ö- pelaamaan tietsikal siel meiän viereises talossa siellä .hh

S: $=$ joo?

$\mathrm{L}:=$ ku me asutaan siin mummin kaa,

S: (..) [joo?

L: [nii- siin viereises talossa .hh (jäätelöö) ja sit sellanen e- konepelejä sellassii pelattiin siellä.

(..)

$\mathrm{S}:$ joo?

(..)

L: $\quad k$-sitten mentiin öö- papalle (...) <sitten s-siellä nii me leikittiin> .hh meiänmaalaisii leikkei sellassii .hh leikittii sitä. (.)

L: ${ }^{\circ}$ joo-o ${ }^{\circ}$

$\mathrm{L}:=$ mun kavereitten kaa ku siel on ${ }^{\circ} \mathrm{myös}^{\circ}$ mun kavereita. (.)

S: $\mathrm{mm}$ (...)

L: sitten me mentiin tonne (..) tonne tivoliin hh [sinne- siellä .hh sit me leikittiin sielki <sitten>

$[\mathrm{mm}$ ?

L: . .hh mentiin tonne (...) .h tonne tonne $>$ mis oli nyt se oli< .hh $>$ no se on $<$ sinntonne juna-asemalle .hh

$\mathrm{S}:=\mathrm{mm}$ ?

L: sit mentii jonnekki taas .hh em mä muista enää. 


\section{Liite 2: SOP-laskentaesimerkit}

SUURIN LEKSIKAALINEN DIVERSITEETTI

\begin{tabular}{|c|c|c|c|c|c|c|c|c|}
\hline sana & $\mathrm{F}$ & $x$ & $r$ & saneita & $p(F=0)$ & $p(F>0)$ & $\mathrm{KL}$ & КTOT \\
\hline tiistai & 1 & 0 & 42 & 254 & 0,834646 & 0,165354 & 0,023810 & 0,003937 \\
\hline perjantai & 1 & 0 & 42 & 254 & 0,834646 & 0,165354 & 0,023810 & 0,003937 \\
\hline lauantai & 4 & 0 & 42 & 254 & 0,483009 & 0,516991 & 0,023810 & 0,012309 \\
\hline aamuisin & 1 & 0 & 42 & 254 & 0,834646 & 0,165354 & 0,023810 & 0,003937 \\
\hline ai & 1 & 0 & 42 & 254 & 0,834646 & 0,165354 & 0,023810 & 0,003937 \\
\hline aika & 2 & 0 & 42 & 254 & 0,696088 & 0,303912 & 0,023810 & 0,007236 \\
\hline ajaa & 1 & 0 & 42 & 254 & 0,834646 & 0,165354 & 0,023810 & 0,003937 \\
\hline asua & 1 & 0 & 42 & 254 & 0,834646 & 0,165354 & 0,023810 & 0,003937 \\
\hline auto & 3 & 0 & 42 & 254 & 0,580073 & 0,419927 & 0,023810 & 0,009998 \\
\hline bussi & 1 & 0 & 42 & 254 & 0,834646 & 0,165354 & 0,023810 & 0,003937 \\
\hline ei & 4 & 0 & 42 & 254 & 0,483009 & 0,516991 & 0,023810 & 0,012309 \\
\hline eläin & 1 & 0 & 42 & 254 & 0,834646 & 0,165354 & 0,023810 & 0,003937 \\
\hline elää & 1 & 0 & 42 & 254 & 0,834646 & 0,165354 & 0,023810 & 0,003937 \\
\hline eno & 2 & 0 & 42 & 254 & 0,696088 & 0,303912 & 0,023810 & 0,007236 \\
\hline esimerkiksi & 1 & 0 & 42 & 254 & 0,834646 & 0,165354 & 0,023810 & 0,003937 \\
\hline esimerkki & 1 & 0 & 42 & 254 & 0,834646 & 0,165354 & 0,023810 & 0,003937 \\
\hline että & 1 & 0 & 42 & 254 & 0,834646 & 0,165354 & 0,023810 & 0,003937 \\
\hline hakea & 1 & 0 & 42 & 254 & 0,834646 & 0,165354 & 0,023810 & 0,003937 \\
\hline harjoitella & 1 & 0 & 42 & 254 & 0,834646 & 0,165354 & 0,023810 & 0,003937 \\
\hline harjoitus & 1 & 0 & 42 & 254 & 0,834646 & 0,165354 & 0,023810 & 0,003937 \\
\hline harrastaa & 1 & 0 & 42 & 254 & 0,834646 & 0,165354 & 0,023810 & 0,003937 \\
\hline herätä & 2 & 0 & 42 & 254 & 0,696088 & 0,303912 & 0,023810 & 0,007236 \\
\hline Hese & 1 & 0 & 42 & 254 & 0,834646 & 0,165354 & 0,023810 & 0,003937 \\
\hline heti & 1 & 0 & 42 & 254 & 0,834646 & 0,165354 & 0,023810 & 0,003937 \\
\hline huomenna & 1 & 0 & 42 & 254 & 0,834646 & 0,165354 & 0,023810 & 0,003937 \\
\hline ihan & 1 & 0 & 42 & 254 & 0,834646 & 0,165354 & 0,023810 & 0,003937 \\
\hline ihminen & 1 & 0 & 42 & 254 & 0,834646 & 0,165354 & 0,023810 & 0,003937 \\
\hline ilta & 1 & 0 & 42 & 254 & 0,834646 & 0,165354 & 0,023810 & 0,003937 \\
\hline Impivaara & 2 & 0 & 42 & 254 & 0,696088 & 0,303912 & 0,023810 & 0,007236 \\
\hline ulos & 1 & 0 & 42 & 254 & 0,834646 & 0,165354 & 0,023810 & 0,003937 \\
\hline uusi & 3 & 0 & 42 & 254 & 0,580073 & 0,419927 & 0,023810 & 0,009998 \\
\hline KAUPUNGINOSA & 1 & 0 & 42 & 254 & 0,834646 & 0,165354 & 0,023810 & 0,003937 \\
\hline vetää & 2 & 0 & 42 & 254 & 0,696088 & 0,303912 & 0,023810 & 0,007236 \\
\hline viikko & 1 & 0 & 42 & 254 & 0,834646 & 0,165354 & 0,023810 & 0,003937 \\
\hline viime & 1 & 0 & 42 & 254 & 0,834646 & 0,165354 & 0,023810 & 0,003937 \\
\hline voittaa & 1 & 0 & 42 & 254 & 0,834646 & 0,165354 & 0,023810 & 0,003937 \\
\hline yhdeksän & 4 & 0 & 42 & 254 & 0,483009 & 0,516991 & 0,023810 & 0,012309 \\
\hline yksi & 1 & 0 & 42 & 254 & 0,834646 & 0,165354 & 0,023810 & 0,003937 \\
\hline yksitoista & 1 & 0 & 42 & 254 & 0,834646 & 0,165354 & 0,023810 & 0,003937 \\
\hline äiti & 2 & 0 & 42 & 254 & 0,696088 & 0,303912 & 0,023810 & 0,007236 \\
\hline yht. 133 & 254 & & & & & & & 34,60996 \\
\hline
\end{tabular}


PIENIN LEKSIKAALINEN DIVERSITEETTI

\begin{tabular}{lrlrrrrrr}
\hline sana & $\mathrm{F}$ & $\mathrm{x}$ & $\mathrm{r}$ & saneita & $\mathrm{p}(\mathrm{F}=0)$ & $\mathrm{p}(\mathrm{F}>0)$ & $\mathrm{KL}$ & $\mathrm{KTOT}$ \\
\hline ei & 18 & 0 & 42 & 66 & 0,000000 & 1,000000 & 0,023810 & 0,023810 \\
hyvä & 1 & 0 & 42 & 66 & 0,363636 & 0,636364 & 0,023810 & 0,015152 \\
joku & 1 & 0 & 42 & 66 & 0,363636 & 0,636364 & 0,023810 & 0,015152 \\
joo & 10 & 0 & 42 & 66 & 0,000009 & 0,999991 & 0,023810 & 0,023809 \\
kanssa & 1 & 0 & 42 & 66 & 0,363636 & 0,636364 & 0,023810 & 0,015152 \\
kaveri & 1 & 0 & 42 & 66 & 0,363636 & 0,636364 & 0,023810 & 0,015152 \\
keksiä & 1 & 0 & 42 & 66 & 0,363636 & 0,636364 & 0,023810 & 0,015152 \\
kärpänen & 1 & 0 & 42 & 66 & 0,363636 & 0,636364 & 0,023810 & 0,015152 \\
mennä & 1 & 0 & 42 & 66 & 0,363636 & 0,636364 & 0,023810 & 0,015152 \\
minä & 12 & 0 & 42 & 66 & 0,000001 & 0,999999 & 0,023810 & 0,023810 \\
olla & 2 & 0 & 42 & 66 & 0,128671 & 0,871329 & 0,023810 & 0,020746 \\
talvi & 1 & 0 & 42 & 66 & 0,363636 & 0,636364 & 0,023810 & 0,015152 \\
tietää & 15 & 0 & 42 & 66 & 0,000000 & 1,000000 & 0,023810 & 0,023810 \\
välitunti & 1 & 0 & 42 & 66 & 0,363636 & 0,636364 & 0,023810 & 0,015152 \\
\hline yht. 14 & 66 & & & & & & & 10,59859 \\
\hline
\end{tabular}

Todennäköisyyden $\mathrm{F}=\mathrm{o}$ laskemisessa on käytetty neljän muuttujan ( $\mathrm{x}, \mathrm{r}, \mathrm{F}$, saneita) hypergeometrista jakaumaa. $K L=1 / r$ eli F:n kontribuutio lemman TTR:ään näytekoolla $r$. KTOT $=p(F>0) \times 1 / r$ eli F:n kokonaiskontribuutio. 
Liite 3: Sukupuolen ja modaliteetin vaikutus leksikaaliseen diversiteettiin

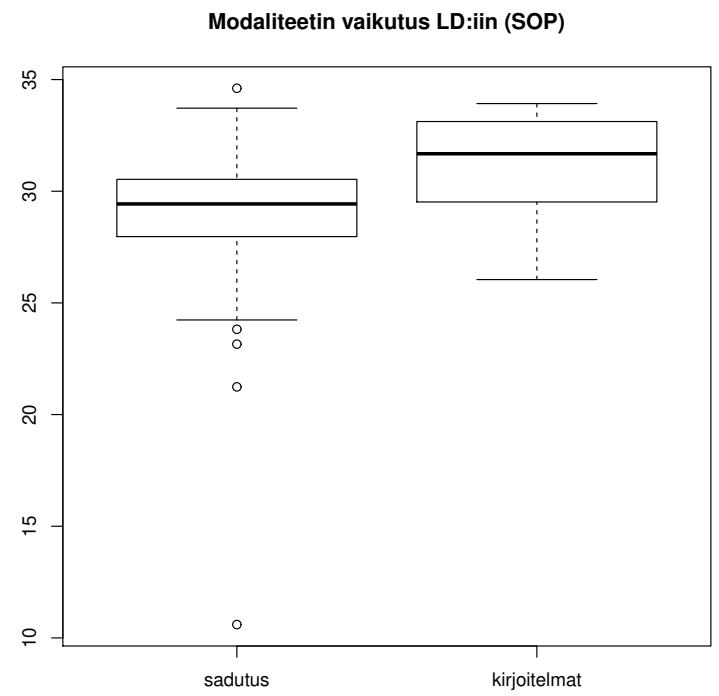

Sukupuolen vaikutus LD:iin (SOP)

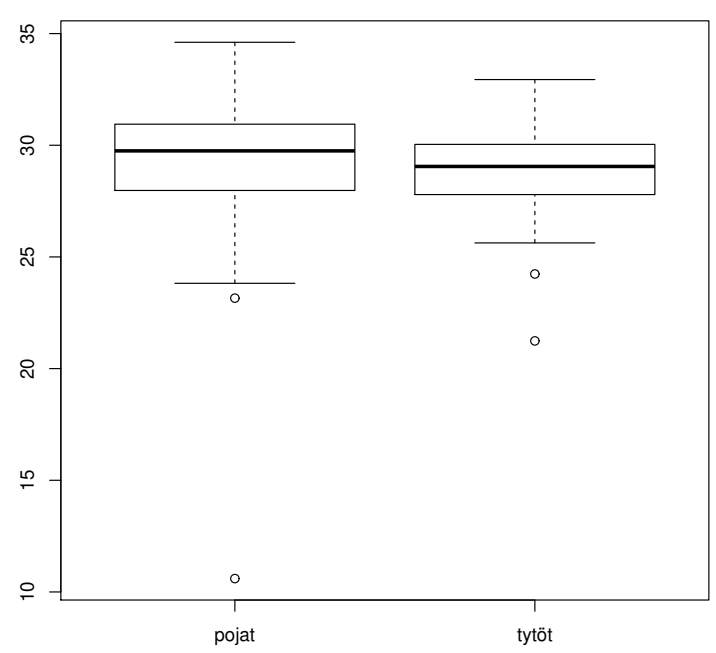




\title{
Liite 4: Esimerkit vuorojäsennyksestä
}

\section{Esimerkkiteksti 1: melko runsas diversiteetti, paljon lyhyitä vuoroja}

\begin{abstract}
olipa kerran X ja minä $\rightarrow$ moltiin kavereita nii ja sit me aina leikittiin toisien kanssa $\rightarrow$ joskus meille tuli r-riitaa $\rightarrow$ ku joskus me tapeltii $\rightarrow$ em mä tiiä enää $\rightarrow$ joskus $\rightarrow$ sit me sovittiin takas $\rightarrow$ pleikkoja $\rightarrow$ pleikka pleikat seedeet jalkapallo kakstuhattaseittemän $\rightarrow$ mitä $\rightarrow \rightarrow$ pelataa $\rightarrow$ tietsikalla $\rightarrow \rightarrow$ pelaa $\rightarrow$ fifa kakstuhattaseittemän $\rightarrow \rightarrow$ no pelataan jalkapalloa $\rightarrow \rightarrow$ me voitetaan $\rightarrow \rightarrow$ joo pokaalin $\rightarrow \rightarrow$ kultanen $\rightarrow$ em mä tiiä $\rightarrow$ moisin myyny sitä pokaalii $\rightarrow$ sitte tehny nukkumaan $\rightarrow$ sille oli vähän- vähän kallis $\rightarrow$ saan paljon rahaa $\rightarrow$ sitten sillä rahalla ostan vaatteita ja kirjoja $\rightarrow$ oisin ainaki ostanu kirjan Risto Räppääjästä $\rightarrow$ mä oon luenu kaks Risto Räppääjä kirjaa $\rightarrow$ nyt mä haluu ostaa nuu- nuudelipää Risto Räppääjän $\rightarrow \rightarrow$ nuudelipää Risto Räppääjän $\rightarrow$ mul on kotona Hilpuri Tilli $\rightarrow$ joskus luen oma kielellä -ki $\rightarrow$ ja eilen luen n-neljä oma kielellä $\rightarrow$ joskus mä paan (paperissa ja kynä) ja kirjotan $\rightarrow$ joskus piirrän autoja $\rightarrow$ kirjotan kaikkee $\rightarrow$ mä harrastan euroliigajalkapalloa $\rightarrow$ kaks vuotta (3. Ik. poika S2)
\end{abstract}

Esimerkkiteksti 2: melko vähäinen diversiteetti, paljon pitkiä vuoroja, vähän tutkijan vuoroja

olipa kerran yksi nalle sen nimi oli Kalle sitten se oli ihan se oli päiväkodissa sit- kun hän- kun se meni kotiin sen äiti tuli hakee niin sit se meni kotiin se söi eka vähän ruokaa vaan sitten se meni pihaan sitten kun sen isä tuli ne meni samaa aikaa kotiin sisään nii sit sen synttärit oli nii sen isä ei oo viel kertonu mitä se otti lahjaks se anto niinku sit ku ne vieraat tuli sen kaverit ja nää nii sit se kerto isäki kerto sille sit se oli tosi iloinen sitten kun ne vieraat meni kotiin toii sen isoveli ja nalle- toi Kalle meni nuk- ne meni nukkuu sit toisena kertana ne meni see Kalle meni kouluun sit se tutustui näihin kaikkeihin kavereitten kaa sitten toisena päivänä ne men- ne meni taas kouluun sit sit ne oli se leikki tosi paljo niitten kaa ja $\rightarrow$ jaa niinkun se niinkun meni luokkaan niil oli käsityötä ne teki ison niinku käsinuken kis- sellasen kissan ja sit- sitten ku se meni kotiin taas sit sen isä ja äiti oli kaupungissa sen äiti- sen isoveli meni oli vielä koulussakin sitten ku se tuli koulusta ne meni yhessä sisään sit ne teki eka läksyt sit ne pelas korteilla $\rightarrow$ ne meni ihan ku uunoa sellasta $\rightarrow$ sit ku sen isä ja äiti tuli ne on ostanu niille vaatteita sit ne sai kokeilla niitä kun toi isä ja äiti ja nää toiset söi ruokaa sit yks niitten kaveri Kallen kaveri ja sen isä on pyytäny niitä että niinku me- niinku että ne menee sinne ne sais sit uudet vaatteet laittaa sit ne tuli takas kotiin ja nee otti 
vaatteet uudet vaatteet pois ja sit meni nukkuun $\rightarrow$ em mä enää muista (2. Ik. tyttö S2)

Yhdellä nuolella on merkitty pitkän mietintätauon tai tutkijan lyhyen vuoron tuoma katkos, kahdella nuolella tutkijan kertomiseen rohkaisu, usein kysymys kuten kerro siitä lisää, mitä sitten tapahtui. Kummassakaan kertomuksessa ei esiinny saduttajalta kierrätettyä leksikaalistan ainesta. 